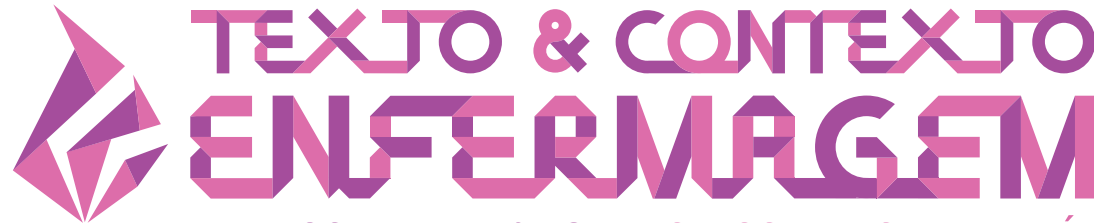

TEXT \& CONTEXT NURSING TEXTO \& CONTEXTO ENFERMERÍA

\section{ELEMENTS OF MORAL SENSITIVITY IN THE PRACTICE OF CLINICAL HOSPITAL NURSES}

\author{
Janaína Cassana Mello Yasin'1 \\ Edison Luiz Devos Barlem ${ }^{1}$ \\ Jamila Geri Tomaschewski Barlem ${ }^{1}$ (D) \\ Gustavo Baade de Andrade ${ }^{1}$ (D) \\ Rosemary Silva da Silveira ${ }^{1}$ (D) \\ Graziele de Lima Dalmolin² (1)
}

\begin{abstract}
'Universidade Federal do Rio Grande, Programa de Pós-Graduação em Enfermagem. Rio Grande, Rio Grande do Sul, Brasil.
\end{abstract} 2Universidade Federal de Santa Maria, Programa de Pós-Graduação em Enfermagem. Santa Maria, Rio Grande do Sul, Brasil.

\begin{abstract}
Objective: to identify the elements of moral sensitivity held by nurses working in a medical clinic unit.

Method: this exploratory-descriptive study with a qualitative approach addressed 18 nurses from a medical clinic of a university hospital located in southern Brazil using semi-structured interviews, which were analyzed using discursive textual analysis.

Results: data were structured into six categories: relational orientation; experiencing moral dilemmas; following rules; benevolent motivation; structuring moral meaning; and autonomy. These categories enabled the identification of important elements of moral sensitivity, such as acknowledging the ethical dimension of one's attitudes, acknowledging the uniqueness of each patient, dealing with conflict between workers and patients and/or their companions, adapting to the workplace, empathy, dialogue, clinical decision-making, meeting the needs of patients, understanding patients' health condition, respect, welcoming patients' desires and providing guidance that concerns patients' requests and refusals.

Conclusion: the elements of moral sensitivity identified in this study contribute to support nurses when making clinical decisions, especially when facing ethical issues arising in a medical clinic setting.
\end{abstract}

DESCRIPTORS: Adult health. Ethics, nursing. Ethics. Moral. Nursing. 


\section{ELEMENTOS DA SENSIBILIDADE MORAL PRESENTES NA ATUAÇÃO DE ENFERMEIROS CLÍNICO-HOSPITALARES}

\section{RESUMO}

Objetivo: identificar os elementos da sensibilidade moral presentes em enfermeiros atuantes em uma Unidade de Clínica Médica.

Método: pesquisa qualitativa, do tipo exploratório-descritiva, desenvolvida por meio de entrevistas semiestruturadas analisadas mediante análise textual discursiva, com 18 enfermeiros atuantes na unidade de clínica médica de um hospital universitário do sul do Brasil.

Resultados: se estruturam em seis categorias: orientação relacional; experimentando o conflito moral; seguir regras; motivação benevolente; estruturação do significado moral e autonomia a qual foi possível identificar importantes elementos da sensibilidade moral como reconhecimento a dimensão ética das atitudes, reconhecer a singularidade dos pacientes, a forma de enfrentamento dos conflitos entre profissional e paciente e/ou acompanhante, adaptação no ambiente de trabalho, empatia, diálogo, tomada de decisão clínica, atendimento as necessidades dos pacientes, compreensão da sua condição de saúde, respeito, acolhimento aos seus desejos e orientação quanto as suas solicitações e recusas.

Conclusão: os elementos da sensibilidade moral identificados nesse estudo contribuem para habilitar os enfermeiros para a tomada de decisão clínica, principalmente diante de problemas éticos vivenciados no ambiente de clínica médica.

DESCRITORES: Saúde do adulto. Ética em enfermagem. Ética. Moral. Enfermagem.

\section{ELEMENTOS DE SENSIBILIDAD MORAL EN EL DESEMPEÑO DE ENFERMERAS CLINICO-HOSPITALARIAS}

\section{RESUMEN}

Objetivo: identificar los elementos de sensibilidad moral presentes en las enfermeras que trabajan en una Unidad de Clínica Médica.

Método: investigación cualitativa, descriptiva exploratoria, desarrollada a través de entrevistas semiestructuradas analizadas mediante análisis discursivo textual, con 18 enfermeras trabajando en la unidad de clínica médica de un hospital universitario en el sur de Brasil.

Resultados: se estructuran en seis categorías: orientación relacional; experimentando conflicto moral; seguir las reglas; motivación benevolente; Estructuración del significado moral y la autonomía que permitieron identificar elementos importantes de la sensibilidad moral, como el reconocimiento de la dimensión ética de las actitudes, el reconocimiento de la singularidad de los pacientes, la forma de hacer frente a los conflictos entre el profesional y el paciente y / o compañero, la adaptación en el entorno de trabajo. , empatía, diálogo, toma de decisiones clínicas, satisfacción de las necesidades de los pacientes, comprensión de su estado de salud, respeto, bienvenida a sus deseos y orientación con respecto a sus solicitudes y rechazos.

Conclusión: los elementos de sensibilidad moral identificados en este estudio contribuyen a que las enfermeras puedan tomar decisiones clínicas, especialmente frente a problemas éticos experimentados en el entorno de la clínica médica.

DESCRIPTORES: Salud del adulto. Ética de enfermería. Ética. Moral. Enfermería. 


\section{INTRODUCTION}

Historically, the philosophical concept of moral sensitivity has been explored with the idea of "moral sense", involving factors such as moral knowledge, moral behavior, and benevolent motivation. ${ }^{1}$ In this context, moral sensitivity is the ability of a worker to identify conflict situations and understand the moral consequences of a decision for a patient, being aware of one's responsibilities. ${ }^{2}$ Hence, ethical decision-making, in turn, involves being sensitive to a patient's vulnerability and express such sensitivity. $^{3}$

Moral sensitivity in the nursing field is understood as a worker's ability to identify the moral component of a given conflict situation and make an ethical decision based on personal values, such as courage, compassion, intelligence and benevolence, and also take into account contextual values such as knowledge and professional experience. . $^{2,4-5}$

Healthcare settings, especially clinical settings, are characterized by various ethically vulnerable situations. ${ }^{6-7}$ Moreover, nurses are constantly confronted with conflicting situations in which their knowledge and skills are put to test. As a consequence, they may find it difficult to perceive, or may even fail to perceive, the ethical dimensions of everyday problems. ${ }^{8}$ Hence, moral sensitivity is considered a characteristic that enables nurses to fully recognize the ethical challenges of a clinical setting, providing them a good understanding of their work situation. ${ }^{9-10}$

There are various elements presented in the international context that influence the moral sensitivity of nurses, namely: relational orientation, structuring moral meaning, experiencing moral dilemmas, autonomy, following rules, moral awareness, moral perception, and benevolent motivation. ${ }^{2,11}$ The elements identified in Brazil include the professional dimension, relationships established with patients, and ethics training. ${ }^{12}$ Understanding such elements is essential to establishing measures that promote a care practice based on ethics and the development of moral sensitivity in healthcare settings, ${ }^{12}$ especially in Brazilian medical clinic units where studies addressing the moral sensitivity of nurses are still incipient.

Thus, this study's objective is to fill in this gap, to verify whether nurses are morally sensitive in perceiving and recognizing ethical problems experienced in the routines of medical clinic units. This need arises from the fact that ethical conflicts are constantly presented in nursing practice, whether in the care, managerial or teaching spheres.

Therefore, the routine decision-making of professionals working in a context where nursing care ranges from very basic to very complex care practices requiring workers to have very clear and humanized decision-making processes grounded in sensitivity, ethical and critical judgment skills. Given the preceding discussion, this study's objective was: to identify the elements of moral sensitivity held by nurses working in a Medical Clinic Unit.

\section{METHOD}

This descriptive exploratory study with a qualitative approach was conducted in a medical clinic unit of a university hospital located in southern Brazil. This hospital exclusively serves users of the Brazilian Unified Health System and has 203 beds. The study setting, a medical clinic unit, has a total of 49 beds: 14 isolation beds and 8 nursing wards with 4 or 5 beds each. The nursing staff is composed of 21 nurses with a weekly workload of 36 hours divided into 4 shifts: morning, evening, night I and night II. All public employees were selected through a public competition by the Brazilian Company of Hospital Services (EBSERH) under the Brazilian Consolidation of Labor Laws.

The project was approved by the Institutional Review Board. Selection criteria were having a work contract with the hospital and not being a temporary worker. Exclusion criteria were not being a 
nurse or being on leave or vacation. Of the 21 nurses, 18 participated in the study; 3 were excluded for not being available at the time of data collection.

Data were collected in June 2018 during working hours, in a private room on the hospital premises, to ensure privacy. Semi-structured interviews were recorded and lasted 25 minutes on average. Interviews contained closed-ended questions to characterize the participants and openended questions addressing aspects related to the elements workers use to make decisions when facing ethical problems, based on moral sensitivity.

Data were analyzed through discursive textual analysis, which is a method to analyze qualitative data and is intended to promote understanding of reports and phenomena. It is based on three stages: unitarization; categorization; and communication. ${ }^{13}$ Ethical aspects were fully respected in accordance with resolution $466 / 2012$. The nurses' reports are identified with the letter $\mathrm{N}$, followed by a sequential number (N1 to N18).

\section{RESULTS}

In regard to the characteristics of the participants: the 18 nurses were aged from 29 to 44 years old; 14 were women; the most advanced degree for 9 was a specialization course beyond a bachelor's degree, while 5 only had a bachelor's degree, 3 had attended a residency program and 1 had a Master's degree. Professional experience ranged from 4 to 19 years, while experience in the medical clinic, the setting of this study, ranged from 3 months to 2 years.

Data were categorized according to the elements that configure moral sensitivity based on international scientific findings,${ }^{14}$ which are six elements titled relational orientation, experiencing moral dilemmas, following rules, expressing benevolence, structuring moral meaning, and autonomy. These six elements established the study's categories. Figure 1 presents the elements that defined the study's categories:

\section{Relational orientation}

- Refers to a concern on the worker's part regarding how actions may compromise relationships with patients;

\section{Experiencing moral dilemma}

- Refers to consequences and conflicts that emerge when performing actions in the face of ethical dilemmas;

Following rules

- Refers to obligations and the need to follow institutional protocols and policies;

\section{Expressing benevolence}

- Refers to the motivation to do what one believes to be "good" linked to patients' interest;

Structuring moral meaning

- Refers to giving limited autonomy to patients, developing actions that do not harm patients' integrity;

Autonomy

- Refers to acknowledging and respecting patients' autonomy;

Figure 1 - Elements that define the study's categorization. ${ }^{14}$ 
Finally, six categories were developed, while units of meaning were selected and assigned to each of these categories, which were titled: relational orientation (involving a recognition of the moral dimension of one's attitudes toward other workers and recognizing particularities for decisionmaking); experiecing moral dilemma (conflicts between workers and patients' companions); following rules (adapting to the work environment); benevolent motivation (empathy, dialogue, appropriate decision-making, and meeting patients' needs); structuring moral meaning (understanding patients' conditions and respecting patients); autonomy (welcoming patients' desires and providing guidance concerning patients' requests and/or refusals). Figure 2 presents the study's categorization process.
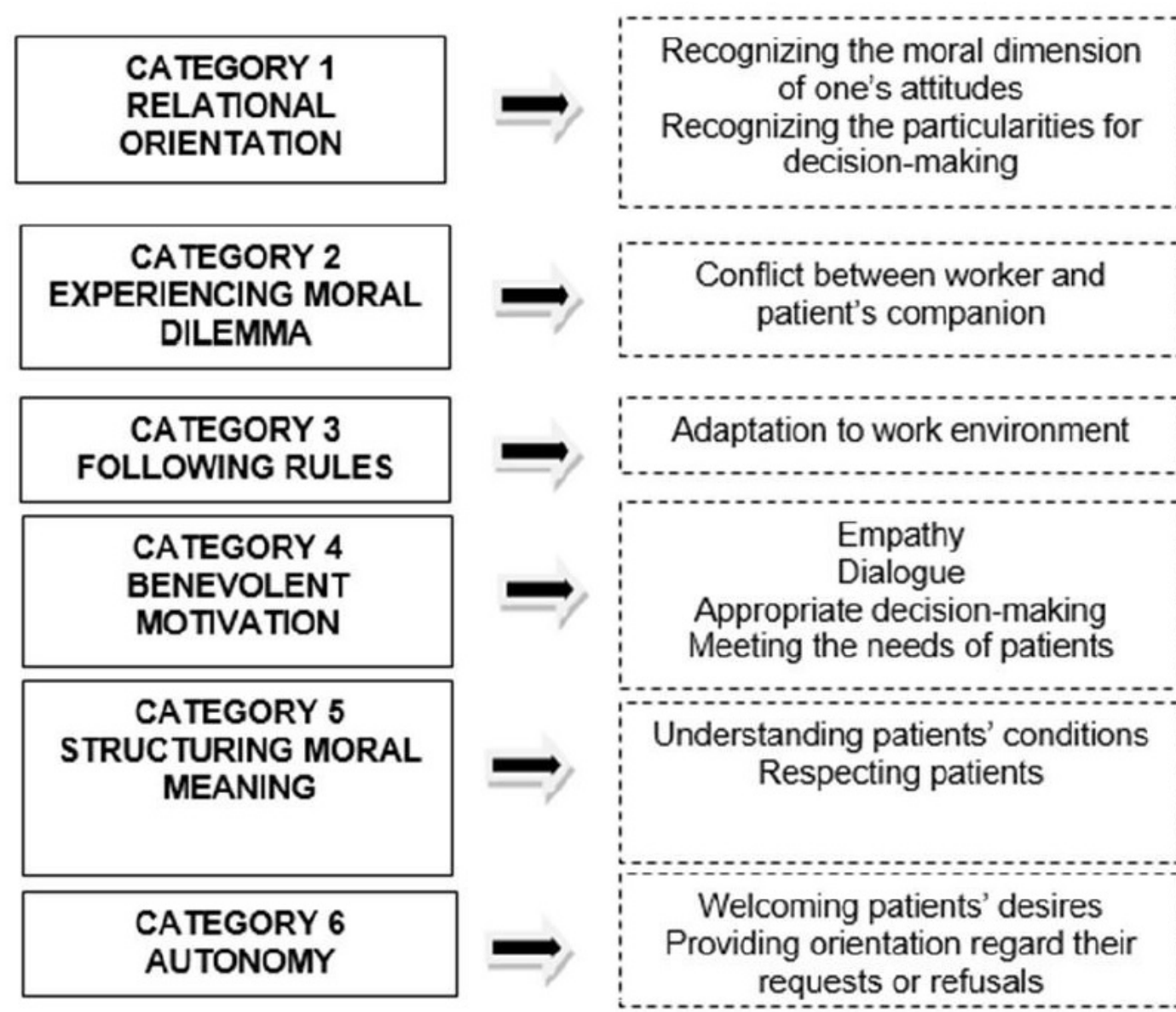

Adaptation to work environment
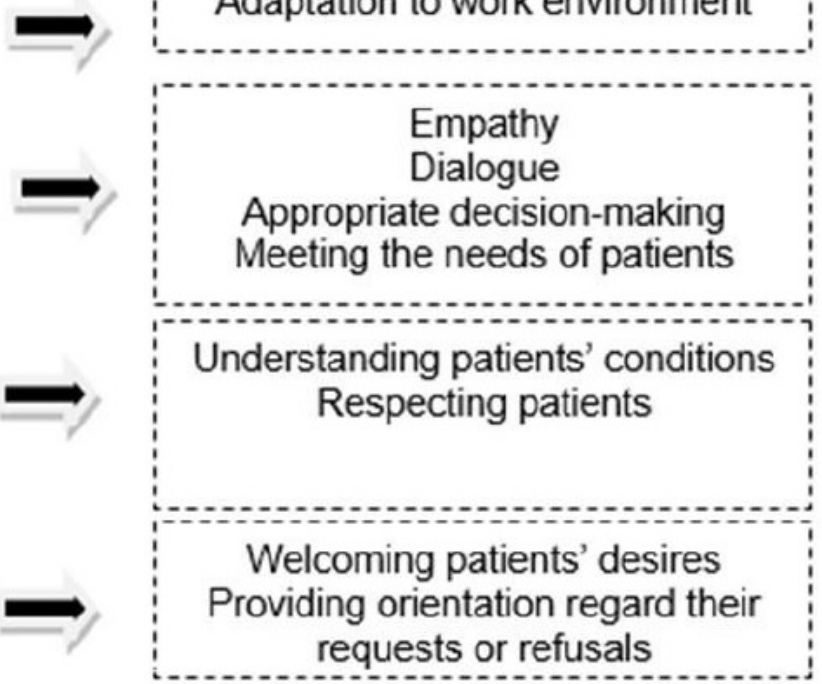

Figure 2 - Structural model of the categories. Rio Grande, RS, Brazil, 2018.

\section{Category 1: relational orientation}

This category shows that the participants seek to develop their professional relationships mainly by recognizing the moral dimension of their attitudes toward other workers. Qualified care is linked to the level of technical knowledge, morality and respect for values, rights and duties of each profession. Nurses are expected to develop their tasks within the medical clinic where the complexity of care ranges from minimal to intensive care and be able to perceive the ethical elements that are present in their routine through moral sensitivity.

Moral sensitivity encompasses a concern on the part of nurses to develop actions that promote patients' wellbeing, respecting both their clinical needs and ethical and cultural aspects. Thus, in regard to relational orientation, nurses believe that qualifying multiprofessional relationships is essential to 
decision-making, establishing conduct such as providing clear orientation and keeping their attention focused on patients, seeking to minimize situations of conflict and establishing ties of trust.

You have to know how to deal with things, how to explain a situation, and try to be as correct as possible, trying to alleviate patients' situations, because it is difficult (N17).

I said "I'm a nurse and if anything happens to him, you know my name, it's me who comes everyday." It was me who was doing, who was administering, it was me who got the prescription and showed him, told him everything, I had to stand up for him (N3).

Another relevant aspect that was verified in the relational orientation category was recognizing the uniqueness of patients and their families. Nurses seem to show that to practice their profession with honor and dignity, it is essential to respect others considering their human condition and provide integral and humanized assistance. The relationships established in a medical clinic setting are extremely conflictive and morally sensitive nurses are better able to resolve ethical conflicts and make decisions based on morally appropriate conduct.

You need to put yourself in others' shoes, because I always tell the girls here, whether you want it or not, people are out of their homes, sharing a room with another four, five people, they are sharing a room with people they don't know (N6).

\section{Category 2: experiencing moral dilemma}

In this category, nurses show that the main problems faced in the unit are related to conflicts existing between workers and patients' companions. Lack of knowledge and lack of patience on the part of family members and/or companions is one of the main causes of moral conflicts. The nurses show better perception of conflicts, making clinical decisions permeated by emotional balance, establishing harmonious relationships with patients and their companions, showing they are morally sensitive.

I had the case of a patient, who was almost dead when he got here, came with no hopes from the ICU, he had AIDS, the doctor told us to take care of him. She started the medications. His relative did not understand why his son had to take all that, thinking that the medications would make his son sick, he would die with so many medications. It was one of the most difficult situations we ever had to face, but the patient is doing well now (N3).

Sometimes family members are rude, they complain because they want the best for their relatives. We have to provide the best service possible (N4).

You are doing everything right, but then a companion comes and complains, for instance, because of a lack of workers, which happens a lot... The companion pushes the patient call bell and wants someone to change a patient's diaper, but see I have 8 technician working with me today, I have 26 bedridden patients, I can change a diaper very fast (N7).

\section{Category 3: following rules}

In this category, the participants report that the elements of moral sensitivity refer to adapting to the work environment, to act in an ethical manner in order to meet organizational interests, as well as personal and professional interests. When nurses develop moral sensitivity, they are able to play their roles with self-determination and have improved problem-solving capacity and act in accordance to their principles, values, institutional standards, human and material resources. Therefore, nurses verify that adapting to the work within the medical clinic is a matter of moral sensitivity, recognizing the use of protocols, using attentive listening and having a clinical perspective to provide quality care to clinical patients:

If this is a hospital, everybody has to do things the same. For this reason, I think that protocols are essential, you have to have protocols and the entire hospital act the same (14). 
Try to make a decision for both. I try to listen to both parts and make a decision that is the best for the staff, that is the best for the work environment (N6).

The professional relationship is an important component of moral sensitivity, because it enables workers to recognize situations of conflict and make decision that take into account professional values, organizational needs, and the patients' real needs. Additionally, nurses are aware that the development of moral sensitivity has a significant impact on the relationships established with other workers and patients, resulting in efficient defense of the patients' interests.

\section{Category 4: benevolent motivation}

In this category, nurses perceive that acting in the way they consider to be correct, linked to the patients' interests, strengthens their judgment and moral motivation to do good, making them more morally sensitive within a medical clinic environment. For this, it is essential that relationships with patients and companions be based on empathy, dialogue, and appropriate clinical decisions, meeting the needs of patients.

Humanization... Sensitivity itself. We see others, we mirror (N2).

I guess that when you put yourself in someone's else shoes, you end up benefiting patients, you think as if you were in his place, I wouldn't want this to happen. So, you guide your practice and that of the staff, you know, care delivery (N13).

I put myself in the patients'shoes, in the employee's shoes, I empathize, it's the worker treating patients well (N15).

Another aspect reported by nurses for their care activities to be performed in a benevolent manner was to establish a dialogue between the staff and patient and/or companion. The dialogue established between clinical nurses and patients and/or companions is essential to coping with ethical conflicts in the context of a medical clinic, where nurses face complex situations that require an honest dialogue that favors decision-making together with all those involved. For that, the participants believe they will be developing moral sensitivity by establishing honest conversations, being able to recognize conflict situations and resolve them more easily.

I always try, even knowing that the mistake was mine, I go back and talk to the patient... I have no haughtiness, I apologize when I see I'm wrong and even when I'm not wrong, I talk and seek a way to improve the relationship (N6).

If the conflicting situation is with a companion, or a patient, it doesn't matter, we go ant talk to the patient and try to ameliorate the problem, depending on what it is. Then, it is a matter of dialoguing, really (N2).

The time I'm here, I have already been able to see things and you realize that the prescription is wrong, the dosage is not right, so you have to ask and say it is wrong. So, you need to know how to talk and dialogue in order to benefit the patient (N17).

Considering that moral sensitivity precedes decision-making, nurses report it is essential at the time of assessing and distinguishing ethical problems, that is, clinical reasoning for good behavior among clinical patients. This way, according to the study's participants, moral sensitivity enables nurses to reinforce their professional autonomy and act with courage and benevolence, being better prepared to make ethical, prudent and fair decisions

We very much tend to do what is fair... Nothing is always fair, but we try to act with benevolence, compassion and courage (N3).

I can't lie to a patient, the thing is to acknowledge the hospital's mistakes and put myself in patients' shoes to make a decision, to have the right posture (N8). 
Nurses in the medical clinic experiences many problems, moral conflicts and dilemmas and the need to use their moral sensitivity to intervene in situations that concern the needs of the unit's patients, even if it entails tasks that are not under their responsibility; that is, patients benefit when their needs are met.

Sometimes I have to do things, but I was there in the maintenance service trying to resolve the problem of a broken shower, which is not my responsibility, but, you know, the one who is listening every single day that a given patient is taking cold showers is me (N9).

There was this patient taking heparin. I called the resident physician and said: Mrs. So-andso is on heparin. Then he says: Ah, but I didn't know that! And I say: Well, I didn't know that she was going to the surgical room either, perhaps if you had talked to me, l'd know and would have postponed it. Then he says: Ah, but it's only a dressing and I answered that it was a bandage only, but she'd bleed, so asked whether he wanted me to send her anyway? So l'd record it on her medical file, then he said, no, in this case, no, postpone it. So I went there to talk to the patient and tell her that the surgery had been postponed (N7).

\section{Category 5: structuring of moral conflict}

The interviewees report that when they understand and acknowledge a patient's condition, they perform actions that do not harm patients. That is, they give meaning to their autonomy, which helps nurses to deal with conflict situations better and perform moral actions. Clinical patients are often in a fragile emotional condition, which makes them more anxious and stressed:

When patients are anxious due to a given treatment, or their condition... We need to know how to deal with the situation, we have to be able to put ourselves in their shoes, think that many patients were active, working but then suddenly saw themselves on a hospital bed... we need to be able to deal with it and deal with situations... (N1).

We have to consider that, sometimes, the conflict patients are facing is precisely because of their conditions. So, we have to take that into account when making decisions (N2).

We have many patients in critical conditions, so sometimes they stress out, become rebellious, aggressive, so you have to be able to deal with them (N17).

Therefore, nurses report that respect for patients precedes morally sensitive decision- making, considering that a diagnosis may often change a patient's life condition completely. Nurses believe that when they respect patients' diseases, treatments, and their emotional, social and religious aspects, they are giving moral significance to patients, thus, making morally sensitive decisions.

I first analyze things...consider that on a given day a given patient may not be well... I think, well, it'll pass; it won't happen later (N1).

Take the best decision possible to not harm anyone (N2).

Now, there was the case of a patient who was evangelical and the staff was bothered that there was a patient praying or something like that. So they asked him to stop praying, so the patient got a little upset and sad, but so far it has not affected anyone (N10).

\section{Category 6: autonomy}

In terms of autonomy, nurses report that the elements of moral sensitivity that give meaning to autonomy in the relationships established with clinical patients include welcoming a patient's desires and properly guiding them in regard to their requests or refusals. Concerning welcoming a patient's desires, the participants believe that listening to patients, allowing them to tell the things that bring them anguish, their beliefs, and needs, nurses are using moral sensitivity. 
By allowing patients to exercise their autonomy within the medical clinic unit, where relationships are intense, nurses act with ethical responsibility and show contextual, cognitive and intuitive understanding of situations, providing qualified care to patients.

Decision-making, to be the best possible, is not to harm anyone, knowing, understanding, and taking the right stand, really (N2).

There is the religious issue, I have seen people have prejudice against some religions... You have to ponder. Why do some religions allow certain things and other do not? So, I try not to judge anything (N10).

I let them say whatever they want, to let the steam off, we explain later... (N8).

\section{DISCUSSION}

Nurses report that the elements of moral sensitivity comprise both professional relationships and relationships established with patients receiving clinical care, permeating interlocutions the ethical dimensions of which are not always acknowledged. These findings corroborate those reported by a study addressing the perceptions of nurses concerning moral sensitivity and its related factors, in which the essential elements of moral sensitivity could be identified both in terms of professional dimensions and aspects that concern the relationships established with patients in addition to ethics training. ${ }^{15}$ Elements of moral sensitivity enable morally inappropriate dimensions that are not always perceived by workers to be identified, allowing nurses to make fair and prudent clinical decisions.

This study enabled identifying elements of moral sensitivity that concern professional relationships, especially in terms of relational orientations established among workers, the organization, patients and family members, reflecting the way nurses address conflicts between workers and companions and adapt to the work environment. One study conducted with nurses in Iran reports that moral conflict leads to adverse consequences both for nurses and patients, ${ }^{16}$ which may directly reflect on ethical decision-making and the quality of care provided to patients.

This study shows that nurses seek to recognize the moral dimension of their attitudes regarding clinical decision-making, which can also be identified in a study addressing nurses working in an intensive therapy unit, which highlighted that workers are more sensitive in recognizing the moral dimension of their behaviors, enabling them to critically and ethically reflect on how they are performing their tasks. ${ }^{17}$ Therefore, a relational orientation based on recognition of the moral dimension is an important component of clinical practice, enabling nurses to better identify the patients' individual needs and clinical decision-making. ${ }^{2,5,18-19}$

Thus, to make morally appropriate clinical decisions, nurses need not only to use clinical reasoning, but also to recognize the uniqueness of each patient and be receptive to a patient's potential vulnerabilities. ${ }^{12,20}$ This statement is in line with this study when participants identify in their reports that, to provide integral, human and sensitive care, they first need to acknowledge the uniqueness of their patients. In this context, moral sensitivity not only sensitizes nurse concerning how to deal with moral issues, but also improves their ability to recognize problems and make ethical decisions being more aware of their responsaiblities. ${ }^{21-22}$

Nurses face many ethical challenges in their professional practice in clinical settings. In regard to these conflicts, note that companions often have difficulties understanding and being patient with the nursing staff, which may hinder decision-making, as reported by a study addressing nursing workers regarding occupational conflicts. ${ }^{12,23}$ In these situations, personal values are permeated by emotional balance, harmony, dialogue, respect and camaraderie as elements of moral sensitivity, which leads workers to be more aware of their actions or omissions. ${ }^{17}$ 
Note that healthcare settings are increasingly unhealthy and exhausting, which leads nurses to experience an overload of problems in their work routine. Given its characteristics of repetition and apparent normality, this often hinders the recognition of the ethical dimension and quality clinical practices. ${ }^{8}$ Hence, the nurses interviewed in this study identify adaptation to the workplace and search for an ethical work environment to be elements that enhance moral sensitivity. An ethical climate in the work context enables nurses to better adapt to their work environment, directly influencing the way they implement their practice. ${ }^{16,24}$ Thus, moral sensitivity enables nurses to recognize and solve ethical problems in their daily work routine and better adapt to their work environment. ${ }^{5}$

Other elements identified here as elements of moral sensitivity include empathy, dialogue, decision-making based on patients' interests, meeting the needs of patients considering their real health conditions, respecting them, welcoming their desires and providing guidance regarding their requests and refusals. In this sense, note that the relationships established with clinical patients and consequently, nursing care, should be based on the fact that a patient is a unique and complex individual, ${ }^{25}$ who requires moral sensitivity from the health worker in order to receive proper support as a patient, in terms of care provided with empathy, understanding, respect and affection.

The results show that the interviewed nurses make decisions based on empathy and honest dialogue. The authors of a Brazilian study addressing the ethical dimension of care states that, when interacting with the multiprofessional team and patients, through the establishment of a clear and concise dialogue, and empathy, nurses are ethically committed to the recipients of care, and are better able to identify vulnerable situations and better develop ethical processes concerning decision-making. ${ }^{19}$ In this sense, moral sensitivity enables nurses to become more committed to care and consequently assume greater responsibility for how actions affect the lives of others, whether patients, staff or companions. ${ }^{6}$

The nurses report that appropriate clinical decision-making and meeting the patients' needs are elements of moral sensitivity, which drive them to act in a benevolent manner. Similarly, the authors of a study addressing nurses in Turkey report that nurses consider themselves to be the ones most responsible for the care provided to their patients, so they were responsible for promoting their patients' wellbeing, ensuring their autonomy and providing good clinical practices. ${ }^{26}$

The authors of a study addressing the perspective of Iranian nursing students regarding factors of moral sensitivity report that students and nurses are considered to be acting with moral sensitivity when they understand patients' conditions, and are able to structure moral meaning and intervene in order to ensure improved efficiency and efficacy of actions, mainly based on critical and reflective reasoning, to minimize risks to patients' mental health. ${ }^{27}$ In this sense, moral sensitivity is essential for ethical, empathic and benevolent decision-making, considering that patients' potential vulnerabilities are acknowledged, ${ }^{22}$ conditions that are similar to the ones presented here.

When it is the case that not even morally-based actions make it possible to develop the expected clinical actions, the participants report they guide patients when they refuse to receive a given treatment, however, always considering and respecting their choices. Similar results show that the moral practice of nurses is linked to the need to make decisions that respect and take into account patients' autonomy, so that they are able to make choices. ${ }^{28}$ Therefore, this study shows that the development of moral sensitivity in medical clinic settings enable nurses to recognize and understand situations in order to defend and prioritize patients' rights.

Moral sensitivity, in turn, should be linked to cognitive and emotional factors for nurses to recognize patients as apt and capable individuals to make their own choices. ${ }^{29}$ In this sense, the ability to perceive ethical dilemmas alone does not ensure just and prudent decision-making, even when developed by moral sensitivity. Decision-making should be linked to other elements, such as critical and clinical reasoning, respect to cultural and educational differences, personal beliefs, respect and 
autonomy and welcoming the desires of patients. ${ }^{30}$ In line with these, the nurses addressed in this study report that, as they welcome the desires of patients and provide orientation in regard to their requests and refusals, they are providing clinical care in accordance to moral sensitivity.

One of this study's limitations is the fact that it has a qualitative approach and addressed a specific sample of nurses working in the medical clinic of a hospital located in the southern Brazil, which does not allow for the generalization of results. Another limiting aspect is a lack of studies addressing moral sensitivity in Brazil, which hinders comparisons between this study's findings and the reality experienced by nurses in different national contexts.

\section{CONCLUSION}

Nurses show that elements of moral sensitivity are based on six categories that comprise both professional relationships and relationships established with patients, showing they are morally sensitive as they recognize the ethical dimension of their attitudes, acknowledge particularities at the time decisions are made, and face the conflicts that take place between workers and patients' companions, and adapt to their work environment. Other aspects that influence nurses' moral sensitivity include empathy, dialogue, clinical decision-making, meeting the needs of patients, understanding patients' health conditions, respecting and welcoming their desires and providing guidance in regard to their requests or refusals. These elements aid workers in making ethical decisions when facing conflicts in the clinical environment.

The results, however, support nurses in the development of an ethical/professional awareness based on ethical and moral values, as well as on personal values, providing them the ability to discuss and defend their ideals, addressing concerns and conflicts. Moral sensitivity enables nurses to identify and differentiate between ethical and routine problems, making them more competent in identify the ethical dimension of problems, and making decisions that benefit patients.

Finally, considering the ethical dimension of this topic, we suggest that moral sensitivity be a topic addressed in continuous education programs provided in hospital facilities, noting there is a need to conduct studies on moral sensitivity in other Brazilian contexts, as these studies will allow comparisons among hospital facilities and enable better understanding of how nurses working in other contexts see moral sensitivity.

\section{REFERENCES}

1. Lützén K, Kvist BE. Moral Distress and its Interconnection with Moral Sensitivity and Moral Resilience: Viewed from the Philosophy of Viktor E. Frankl. J Bioeth Inq [Internet]. 2013 Oct [cited 2018 May 21]; 10(3):317-24. Available from: https://dx.doi.org/10.1007/s11673-013-9469-0

2. Lützén K, Dahlqvist V, Eriksson S, Norberg A. Developing the concept of moral sensitivity in health care practice. Nurs Ethics [Internet]. 2006 [cited 2018 May 14];13(2):187-96. Available from: https://dx.doi.org/10.1191/0969733006ne837oa

3. Nejadsarvari N, Abbasi M, Borhani F, Ebrahimi A, Rasooli H, Kalantar Motamedi MH, et al. Relationship of moral sensitivity and distress among physicians. Trauma Mon [Internet]. 2015 May [cited 2018 May 15];20(2):e26075. Available from: https://dx.oi.org/10.5812/traumamon.26075

4. Weaver K, Morse J, Mitcham C. Ethical sensitivity in professional practice: concept analysis. J Adv Nurs [Internet]. 2008 June [cited 2018 May 15];62(5):607-18. Available from: https://dx.doi. org/10.1111/j.1365-2648.2008.04625.x 
5. Nora CRD, Zoboli ELCP, Vieira M. Sensibilidade Moral dos Enfermeiros Avaliada por Scopin de Review. Cogitare Enferm [Internet]. 2017 [cited 2018 May 15];22(2):e47162. Available from: https://dx.doi.org/10.5380/ce.v22i2.47162

6. Borhani F, Abbaszadeh A, Mohamadi E, Ghasemi E, Hoseinabad-Farahani MJ. Moral sensitivity and moral distress in Iranian critical care nurses. Nurs Ethics [Internet]. 2017 June [cited 2018 May 15];24(4):474-82. Available from: https://dx.doi.org/10.1177/0969733015604700

7. Tuvesson $\mathrm{H}$, Lützén $\mathrm{K}$. Demographic factors associated with moral sensitivity among nursing students. Nurs Ethics [Internet]. 2017 Nov [cited 2018 May 15]; 24(7):847-55. Available from: https://dx.doi.org/10.1177 / 0969733015626602

8. Barlem ELD. Sensibilidade moral e formação profissional de enfermagem. Rev Enferm UFSM [Internet]. 2018 [cited 2018 May 15];8(1):1-2. Available from: https://dx.doi. org/10.5902/2179769229253

9. Kalaitzidis E, Schmitz K. A study of an ethics education topic for undergraduate nursing students. Nurs Educ Today [Internet]. 2014 Jan [cited 2018 May 15];34(1):1443-9. Available from: https:// dx.doi.org/10.1016/j.nedt.2011.02.006

10. Rahnama F, Mardani-Hamooleh M, Kouhnavard M. Correlation between moral sensitivity and self-esteem in nursing personnel. J Med Ethics Hist Med [Internet]. 2017 Dec [cited 2018 May 22];10:16. Available from: https://www.ncbi.nlm.nih.gov/pmc/articles/PMC6150914/

11. Boonyamanee $B$, Suttharangsee $W$, Chaowalit $A$, Parker ME. Exploring moral sensitivity among Thai psychiatric nurses. Songklanagarind J Nurs [Internet]. 2014 [cited 2018 May 14];34:35-43. Available from: https://www.nur.psu.ac.th/journal/file/98file2733.pdf

12. Dalla Nora CR, Zoboli E, Vieira MM. Sensibilidade moral e fatores relacionados: percepção de enfermeiros. Cogitare Enferm [Internet]. 2016 [cited 2018 May 14];21(4):1-8. Available from: http://dx.doi.org/10.5380/ce.v21ii4.47410

13. Moraes R, Galiazzi MC. Análise Textual Discursiva. 2nd ed. Ijuí, RS (BR): Ed. Unijuí; 2011.

14. Lützén K, Johansson A, Nordström G. Moral Sensitivity: some differences between nurses and physicians. Nurs Ethics [Internet]. 2000 Nov [cited 2018 May 21];7(6):520-30. Available from: https://dx.doi.org/10.1177/096973300000700607

15. Dalla Nora CR, Zoboli ELCP, Vieira MM. Moral sensitivity in Primary Health Care nurses. Rev Bras Enferm [Internet]. 2017 [cited 2018 May 15];70(2):308-16. Available from: https://dx.doi. org/10.1590/0034-7167-2016-0453

16. Amiri E, Hossein E, MaryamV, Jafarabadi AM, Hossein AA. Relationship between nurses' moral sensitivity and the quality of care. Nurs Ethics [Internet]. 2018 [cited 2018 June 11];20(10):1-9. Available from: https://dx.doi.org/10.1177/0969733017745726

17. Silveira RS, Martins CR, Lunardi VL, Vargas MAO, Lunardi WD Filho, Avila LI. A dimensão moral do cuidado em terapia intensiva. Cienc Cuid Saude [Internet]. 2014 [cited 2018 May 21];13(2):32734. Available from: https://dx.doi.org/10.4025/cienccuidsaude.v13i2.19235

18. Lützén K, Nordström G, Evertzon M. Moral sensitivity in nursingpractice. Scand J Caring Sci [Internet]. 1995 [cited 2018 May 15];9(3):131-8. Available from: https://dx.doi.org/10.1590/00347167-2016-0453

19. Nascimento MG, Costa TRS, Costa MJB, Lima KAS, Rocha TMP, Santos JC. Dimensões éticas envolvidas no cuidado de enfermagem: uma revisão de literatura. Veredas Favip [Internet]. 2015 [cited 2018 May 14];8(2):120-30. Available from: http://veredas.favip.edu.br/ojs/index.php/ veredas $1 /$ article/view/177/330 
20. Assis MMA, Nascimento MAA, Pereira MJB, Cerqueira EM. Comprehensive health care: dilemas and challenges in nursing. Rev Bras Enferm [Internet]. 2015 [cited 2018 May 19];68(2):333-8. Available from: https://dx.doi.org/10.1590/0034-7167.2015680221i

21. Lützén K, Cronqvist $A$, Magnusson A, et al. Moral stress: synthes is of a concept. Nurs Ethics [Internet] 2003 May [cited 2018 May 15];10(3):312-22. Available from: https://dx.doi. org/10.1191/0969733003ne608oa

22. Baykara ZG, Demir SG, Yaman S. The effect of ethics training on students recognizing ethical violations and developing moral sensitivity. Nurs Ethics [Internet]. 2015 Sept [cited 2018 May 14];22(6):661-75. Available from: https://dx.doi.org/10.1177/0969733014542673

23. Schaefer R, Vieira M. Competência ética como recurso de enfrentamento do sofrimento moral em enfermagem. Texto Contexto Enferm [Internet]. 2015 Apr-June [cited 2018 May 21];24(2):56373. Available from: https://dx.doi.org/10.1590/0104-07072015001032014

24. Jaafarpour $M$, Khani $A$. Evaluation of the nurses job satisfaction, and its association with their moral sensitivities and well-being. J Clin Diagn Res [Internet]. 2012 Dec [cited 2018 May 25];6(10):1761-4. Available from: https://dx.doi.org/10.7860/JCDR/2012/4068.2638

25. Santos JBS, Carvalho DMS, Fonseca MM, Silva FP. Assistência integral de enfermagem aos pacientes em cuidados paliativos. Rev Saúde [Internet]. 2017 [cited 2018 May 15];11(1):36. Available from: http://revistas.ung.br/index.php/saude/article/view/3122

26. Buyuk TE, Rizalar S, Güdek E. Ethical sensitivity, job satisfaction and related factors of the nurses working in different áreas. Prog Health Sci [Internet]. 2015 [cited 2018 May 15];5(1):138-49. Available from: https://dx.doi.org/10.2174/1874434601711010001

27. Borhani F, Abbaszadeh A, Mohsenpour M. Nursing students" understanding of factors influencing ethical sensitivity: A qualitative study. Iran J Nurs Midwifery Res [Internet]. 2013 Jul-Aug [cited 2018 Jul 11];18(4):310-5. Available from: https://www.ncbi.nlm.nih.gov/pmc/articles/PMC3872867/

28. Lee $\mathrm{HL}$, Huang $\mathrm{SH}$, Huang $\mathrm{CM}$. Evaluating the effect of three teaching strategies on student nurses" moral sensitivity. Nurs Ethics [Internet]. 2017 Sept [cited 2018 Jul 22];24(6):732-43. Available from: https://dx.doi.org/10.1177/0969733015623095

29. Savieto RM, Leão ER. Assistência em Enfermagem e Jean Watson: Uma reflexão sobre a empatia. Esc Anna Nery [Internet]. 2016 [cited 2018 May 14];20(1):198-202. Available from: https://dx.doi.org/10.5935/1414-8145.20160026

30. Ahn SH, Yeom HA. Moral sensitivity and critical thinking disposition of nursing students in Korea. Int J Nurs Pract [Internet]. 2014 Oct [cited 2018 May 14]; (5):482-9. Available from: https://dx.doi. org/10.1111/ijn.12185 


\section{NOTES}

\section{ORIGIN OF THE ARTICLE}

Article extracted from the thesis - Moral sensitivity of nurses from adult clinical hospitalization unit, presented to Programa de Pós-Graduação em Enfermagem Universidade Federal do Rio Grande, in 2018.

\section{CONTRIBUTION OF AUTHORITY}

Study design: Yasin JCM, Barlem ELD, Barlem JGT, Andrade GB, Silveira RS, Dalmolin GL. Data collect: Yasin JCM, Barlem ELD, Barlem JGT, Andrade GB, Silveira RS, Dalmolin GL.

Data analysis and interpretation: Yasin JCM, Barlem ELD, Barlem JGT, Andrade GB, Silveira RS, Dalmolin GL.

Discussion of the results: Yasin JCM, Barlem ELD, Barlem JGT, Andrade GB, Silveira RS, Dalmolin GL. Writing and / or critical review of content: Yasin JCM, Barlem ELD, Barlem JGT, Andrade GB, Silveira RS, Dalmolin GL.

Review and final approval of the final version: Yasin JCM, Barlem ELD, Barlem JGT, Andrade GB, Silveira RS, Dalmolin GL.

\section{FUNDING INFORMATION}

This study was financed by the Conselho Nacional de Desenvolvimento Cientifico e Tecnológico (CNPq), number:401582/2016-7.

\section{APPROVAL OF ETHICS COMMITTEE IN RESEARCH}

Approved by the Ethics Committee in Research with Human Beings of the Universidade Federal de Rio Grande, N. n 88/2018Certificate of Presentation for Ethical Appreciation (CAAE): 88866518.4.0000.5324.

\section{CONFLICT OF INTEREST}

There is no conflict of interest.

\section{HISTORICAL}

Received: March 07, 2019

Approved: July 26, 2019

\section{CORRESPONDING AUTHOR}

Janaína Cassana Mello Yasin

janinhacm3@hotmail.com 